\title{
Correction to: Serum CCL20 combined with IL-17A as early diagnostic and prognostic biomarkers for human colorectal cancer
}

\author{
Dan Wang ${ }^{1,2 \dagger}$, Weitang Yuan ${ }^{3 \dagger}$, Yaping Wang ${ }^{1 \dagger}$, Qian Wu ${ }^{1,2}$, Li Yang $^{1,2}$, Feng Li $\mathrm{L}^{1,2}$, Xinfeng Chen ${ }^{1,2}$, Zhen Zhang ${ }^{1,2}$, \\ Weina $\mathrm{Yu}^{1,2}$, Nomathamsanqa Resegofetse Maimela ${ }^{1,2}$, Ling CaO ${ }^{1,2}$, Dong Wang ${ }^{1,2}$, Junxia Wang ${ }^{4}$, \\ Zhenqiang $\mathrm{Sun}^{3}$, Jinbo $\mathrm{Liu}^{3}$ and Yi Zhang ${ }^{1,2,5,6^{*}}$
}

\section{Correction to: J Transl Med (2019) 17:253}

https://doi.org/10.1186/s12967-019-2008-y

The authors of the original article [1] have found out after publication that there were 2 figure errors in the article:

1. The ROC curves of the CCL20-IL-17A panel in Figure $4 \mathrm{C}$ and $4 \mathrm{D}$ were the same as that in the Figure $5 \mathrm{~B}$ and $5 \mathrm{C}$.

2. There is an image crack in the Figure $5 \mathrm{~A}$ during a layer merging process.
These changes don't affect any conclusions of the original paper.

The incorrect (Figs. 1 and 2) and correct figures (Figs. 3 and 4) are published in this correction article. The areas with the errors are indicated with a blue box. The original article has been updated. to the material. If material is not included in the article's Creative Commons licence and your intended use is not permitted by statutory regulation or exceeds the permitted use, you will need to obtain permission directly from the copyright holder. To view a copy of this licence, visit http://creativecommons.org/licenses/by/4.0/. The Creative Commons Public Domain Dedication waiver (http://creativeco mmons.org/publicdomain/zero/1.0/) applies to the data made available in this article, unless otherwise stated in a credit line to the data. 

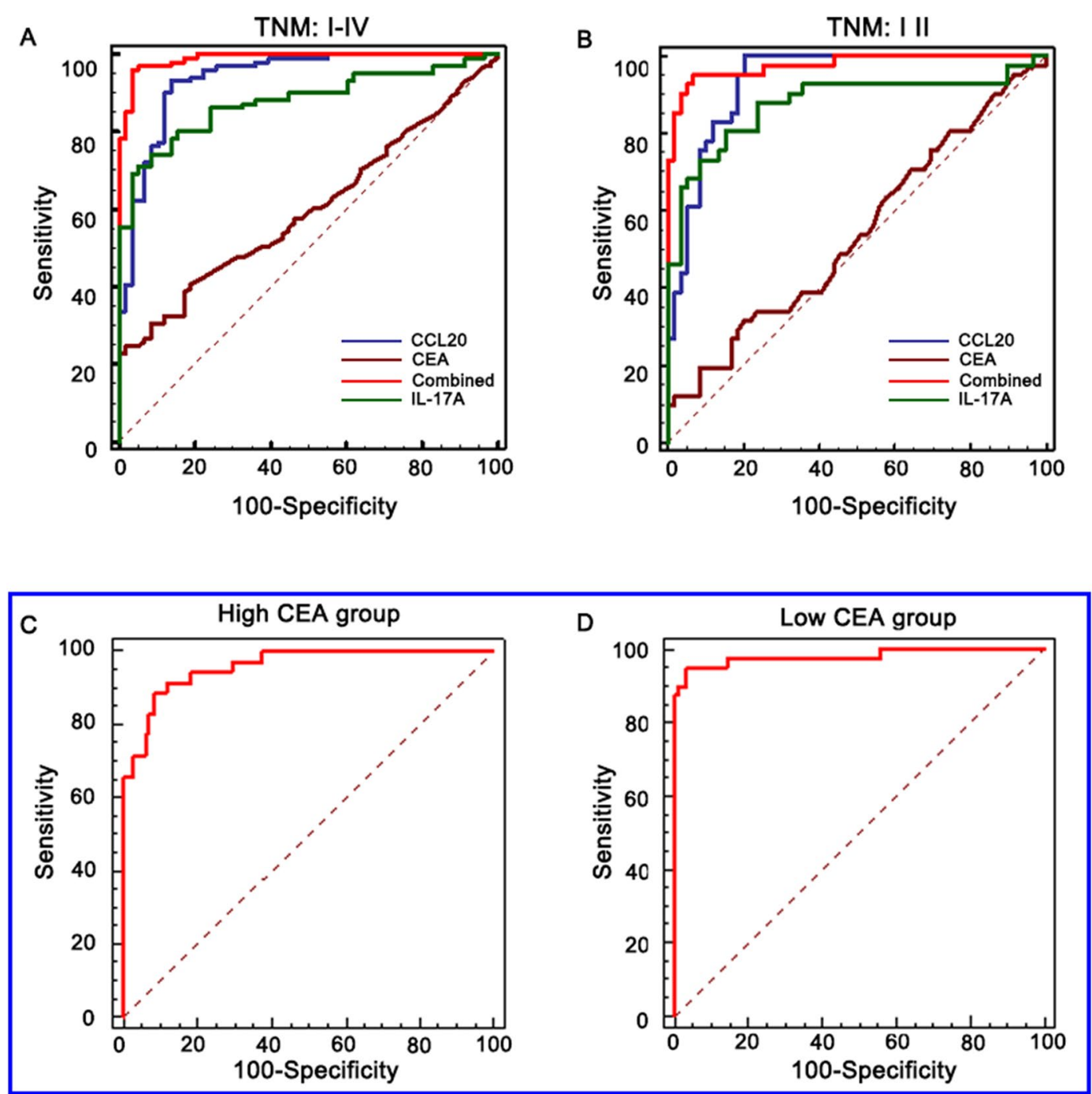

Fig. 1 Incorrect version of Figure 4
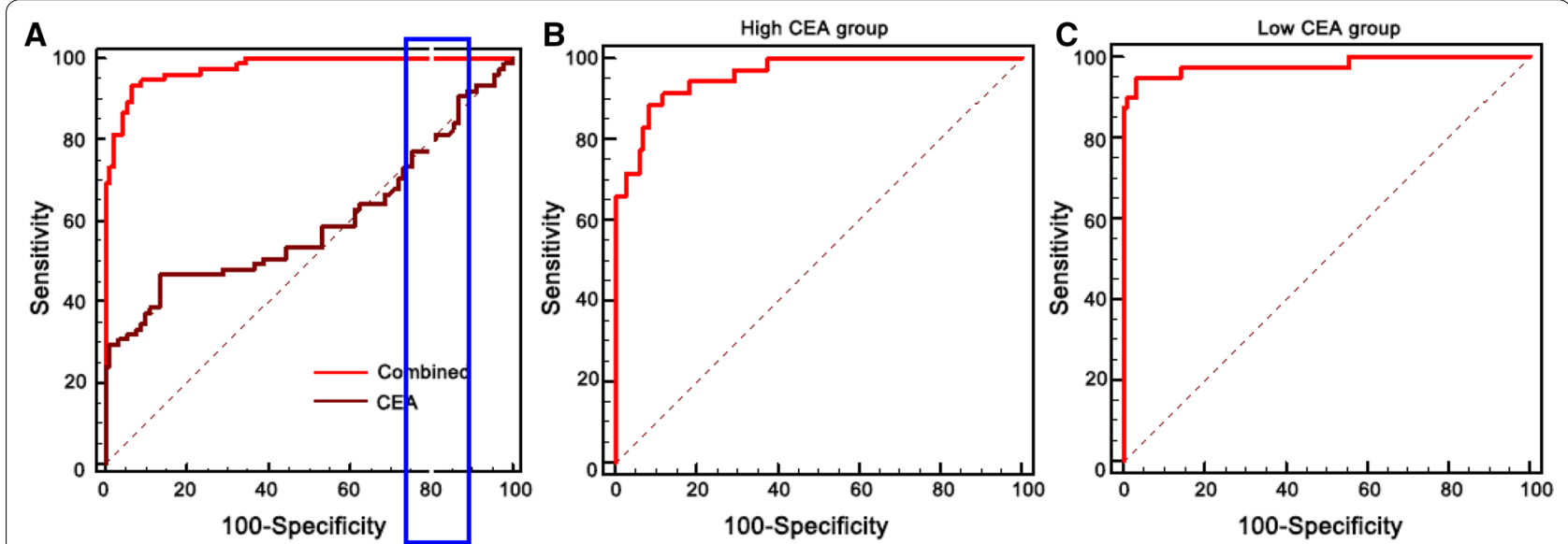

Fig. 2 Incorrect version of Figure 5 

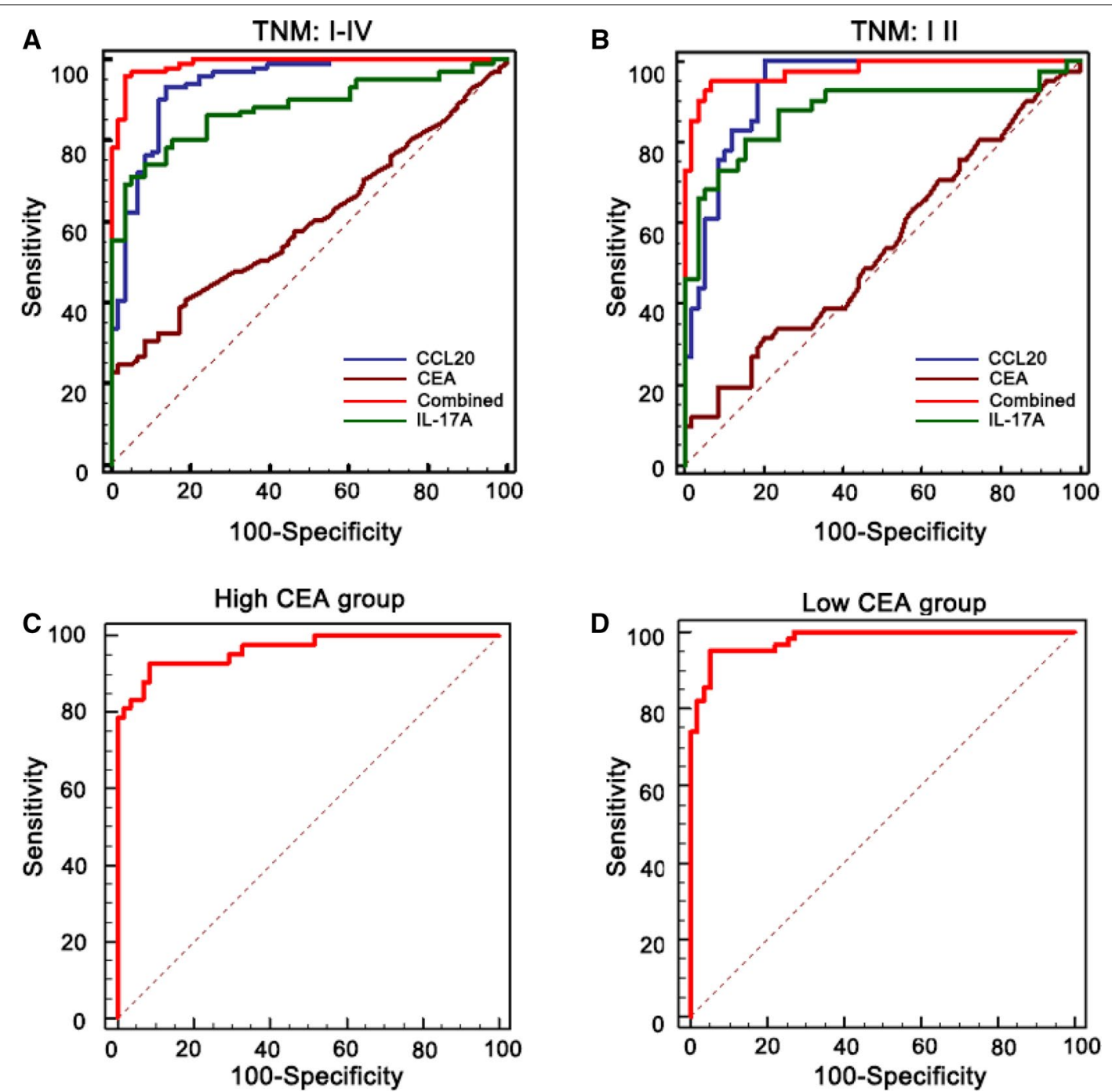

Fig. 3 Correct version of Figure 4
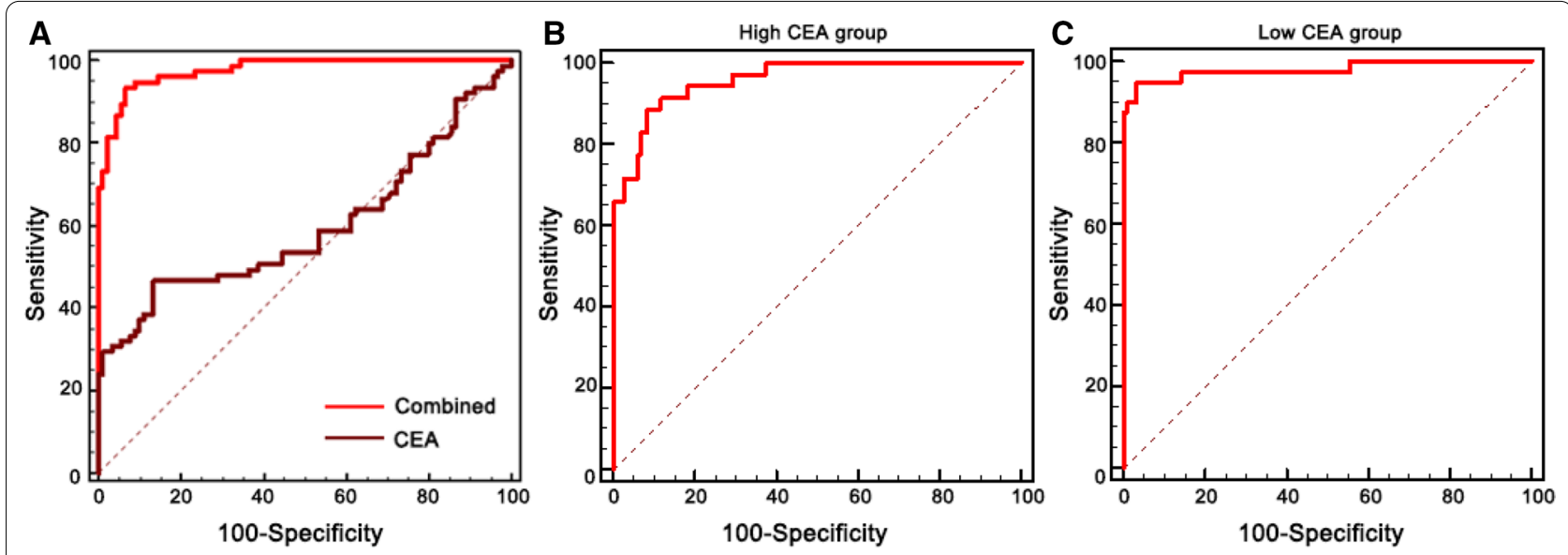

Fig. 4 Correct version of Figure 5 


\section{Author details}

'Biotherapy Center, The First Affiliated Hospital of Zhengzhou University, Zhengzhou 450052, Henan, People's Republic of China. ${ }^{2}$ Cancer Center, The First Affiliated Hospital of Zhengzhou University, Zhengzhou 450052, Henan, China. ${ }^{3}$ Department of Anorectal Surgery, The First Affiliated Hospital of Zhengzhou University, Zhengzhou 450052, Henan, China. ${ }^{4}$ Department of Gastrointestinal Surgery, The First Affiliated Hospital of Zhengzhou University, Zhengzhou 450052, Henan, China. ${ }^{5}$ School of Life Sciences, Zhengzhou University, Zhengzhou 450052, Henan, China. ${ }^{6}$ Henan Key Laboratory for Tumor Immunology and Biotherapy, Zhengzhou 450052, Henan, China.

\section{Reference}

1. Wang D, Yuan W, Wang Y, Wu Q, Yang L, Li F, Chen X, Zhang Z, Yu W, Maimela NR, Cao L, Wang D, Wang J, Sun Z, Liu J, Zhang Y. Serum CCL20 combined with IL-17A as early diagnostic and prognostic biomarkers for human colorectal cancer. J Transl Med. 2019;17:253. https://doi.org/10. 1186/s12967-019-2008-y.

\section{Publisher's Note}

Springer Nature remains neutral with regard to jurisdictional claims in published maps and institutional affiliations.

Published online: 18 October 2021

Ready to submit your research? Choose BMC and benefit from:

- fast, convenient online submission

- thorough peer review by experienced researchers in your field

- rapid publication on acceptance

- support for research data, including large and complex data types

- gold Open Access which fosters wider collaboration and increased citations

- maximum visibility for your research: over $100 \mathrm{M}$ website views per year

At BMC, research is always in progress.

Learn more biomedcentral.com/submissions 